\title{
Local Government: Constitutional Vision and Present Practice
}

By Pradhan, Krishna Man

Mr. Pradhan is pursuing (Ph D) in Political Science and Executive Director, Nepal Law Society can be corresponded at

\begin{abstract}
s
Is it local government or local level unit of provincial and federal level governments? The constitution is still unclear. The constitution has not any provision of opposition party but it has executive, legislative and judiciary power allocation system of the organs of a government. To explore the vision and practice of local governance in Nepal, the study has been conducted. The methodology consists of analyzing primary and secondary sources. Primary data have been collected through field discussions with the stakeholders. Regarding the local governance various recommendations are presented in conclusion.
\end{abstract}

Keywords: Constitution, Local Governance, Nepal

\section{Introduction}

Local governments are the foundations of democratic governance. They are, in real sense, the governments of the citizens. Local governments are the governments in the neighborhood, and the governments in the doorsteps. One of the widely articulated and accepted definitions of democracy as propounded by US President Abraham Lincoln states that democracy is a system of the people, for the people and by the people (Haney, J. 1944). Here, President Lincoln has put people at the center-stage of democracy. One important way the democracy has espoused this centrality is through its expansion and extension up to the local level. Some democratic countries have embraced the concept of federalism while others have stuck to unitary system of governance (Suhrke, 2014). But all of them have strived to deliver it at doorsteps of communities. As such, democracy and local governance have emerged as twin concepts that are integral and complimentary to each other. Local government is the administration of a particular county or district, with representatives elected by those who live there. A local government is a form of public administration which, in a majority of contexts, exists as the lowest tier of administration within a given state (UK Government, 2016).

Strong argument prevailing across the world is that, the trend of delivering service to the 
people through the development and strengthening of local bodies has expanded. According to International IDEA, the forces of change fostering democratization at the local level have gathered so much momentum in recent years that they can only be resisted at one's own peril. Democracy has become the legitimate demand of all local communities. Today more than 70 countries in various parts of the world are in the process of implementing political and administrative reforms aimed at decentralizing and strengthening local governance (Sisk, 2001).

Democracy in the true sense, therefore, is a form of decentralized system of governance. While viewing this phenomenon from purely ideological perspective, one has to consider the challenges facing the democratic governments of today - how their responsibilities have increased day by day along with the ever increasing expectation of the people in terms of efficient, quick and quality of service delivery. One of the logics was it is not possible for the governments in the center to carry out all of their responsibilities, nor be it practical. Therefore, instead of concentrating all functions at one level, the concept of devolving authorities has evolved. It underlines the need for functionaries at local level to carry out functions that need to be fulfilled at that very level. In other words, 'the process of handing over the functions of the central government to the local bodies is decentralization.' Analyzing from political perspective, a state can become efficient and effective if more and more rights are handed over to the local elected officials and less and less rights are kept at the center. The works of public welfare and development can be better dealt by the local level in a fast and efficient manner. Governance through the elected local level officials would be in keeping with the principles of democracy and decentralization as well. It improves the state of answerability and accountability, as well as enhances public participation. It helps in local leadership development and maximum utilization of local resources meaning that by strengthening local levels the tenets of democracy can be taken to the people thus aiding to attain its fundamental goals.

In Nepal, too, the concept of local governance is an old one. But the nature and form of its practice have changed over time. From petty village units to full-fledged elected local governments, the journey has been significant. From the administrative outposts practiced during Kirat/Malla era up to Rana regime to the decentralization, devolution and federalism, this journey has seen progressive changes in keeping with the global movement (Bhattarai, 2008).

Presently, the local governance in Nepal has taken the shape of modern global democratic value. After the gap of two decades, the local governance in Nepal resumed through the elections in 2017. It was the first election held under the new constitution. Mayors, deputy mayors, chairperson, vice chairperson, members of municipalities and rural municipalities were elected. 
It has been two and a half years since the new local governments have started functioning. The new constitution presents the local governments as powerful, functional and autonomous units of government. However, there are still numerous challenges in translating the constitutional provisions into practice. Local government is the closest government of the local people for their day to day life (Badal, 2019).

There is a need to examine the role of local level government in the functioning of democracy at the grassroots. One needs to review development process of local level government in strengthening democracy; assess the impact of democratization on the role, responsibilities, functioning and effectiveness of local governments; evaluate roles and responsibilities of local level government in the changing context; identify challenges of local governments; assess the gap in envisioned role and actual roles of local level governments; evaluate the institutional viability of the local level government in delivering the constitutional obligations and duties; and recommend policy reforms in ensuring the sustainable and viable institutional development of the local level government.

\section{Methods}

In order to examine the research questions, the method of descriptive analysis has been employed. The methodology consists of analyzing primary and secondary sources. Primary data have been collected through field discussions with the stakeholders. Discussions were held with Chairperson/ Vice chairperson; Mayor/Deputy Mayor of the Rural Municipalities and Municipalities; Province Assembly members; Leaders of Political Parties; and Government Officials - Officials of rural municipalities and municipalities; Ministry of Local Development; Ministry of Law and Justice.

Secondary data have been collected through the review of available research, reports and documents - both Nepalese and international from published and non-published sources and e-research focusing on local self-governance, decentralization, and democracy dealing with the theoretical perspective as well as in the specific case of Nepal. Secondary sources of information and data included governmental and non-governmental documents; election manifestoes of different political parties; speeches given by the political leaders on the theme; and non-formal talks with different local government officials, bureaucrats, and political leaders. 


\section{Discussions}

\section{Local Governments: Authority, Roles and Functions}

Democracy is a system of government where the citizens exercise power by voting. Direct democracies, wherein the citizens as a whole form a governing body and vote directly on each issue have become impractical leading to the emergence of representative democracy, where the citizens elect representatives. In a liberal democracy the powers of the majority are exercised within the framework of a representative democracy, but the constitution limits the majority and protects the minority, usually through the enjoyment by all of certain individual rights, e.g. freedom of speech, or freedom of association (Watkins, 1970). John Locke wrote: "There is no practical alternative to majority political rule - i.e., to taking the consent of the majority as the act of the whole and binding every individual. It would be next to impossible to obtain the consent of every individual before acting collectively ... No rational people could desire and constitute a society that had to dissolve straightaway because the majority was unable to make the final decision and the society was incapable of acting as one body (Locke, 2009).

According to American political scientist Larry Diamond, democracy consists of four key elements: a political system for choosing and replacing the government through free and fair elections; the active participation of the people, as citizens, in politics and civic life; protection of the human rights of all citizens; a rule of law, in which the laws and procedures apply equally to all citizens (Diamond, 2004). In the United Kingdom which originated the Westminster system, the basic principle is parliamentary sovereignty, while ensuring judicial independence. In the United States, separation of powers is often regarded as a central attribute (UK Parliament, 2014). In India, parliamentary sovereignty is subject to the Constitution of India that includes judicial review (Daily Express News, 2 August 2013).

Local governance has evolved as modern integral part of democracy. The term local selfgovernment had been used for the first time in the United Kingdom and Germany. It developed between the 15th and 17th centuries. Modern local government is based on twofold foundation of deconcentration and decentralization of central convenience and a recognition that not all authority ought to be exerted by the center. Conferring of power to local level is supported by need for (1) intimate local knowledge and variation, (2) intensity of local interest and enlistment of loyalty and cooperation, (3) small areas for easy impact of the citizen-consumers upon officialsproducers, (4) an accessible area of political education, (5) counterweight to the abuse of central power, and (6) the democratic value of a plurality of political experience and confidence. The chief characteristics of local government, based on the practices at the United Kingdom, Germany, 
the U.S., and Russia, are (1) constitutional status, (2) areas and authorities, (3) powers, (4) finance and local freedom, (5) organization, and (6) central controls (Przeworski, 1991).

More concept has developed that helps capture and assess its roles and functions.

"Local Government is that part of the government, which deals mainly with local affairs administered by authorities' subordinate to the state government but elected independently of the state authority by the qualified residents" (Quoted in Shrestha, 1996: 6). "Local Government as the administration of a locality - a village, a city or any other area smaller than the state - by a body representing the local inhabitants, possessing a fairly large amount of authority, raising at least a part of its own revenue through local taxation and spending its income on services which are regarded as local and therefore distinct from state and central services" (Shrestha, 1996: 6-7). "Local Government is self-government involving the administration of public affairs in each locality by a body of representatives of the local community. Although subject to the central government in many ways it possesses a considerable amount of responsibility and discretionary power" (Byrne, 1981).

"Broadly speaking, the term local self-government is connected with mainly two aspects - governance and development. The concept of governance is closely associated with decentralization as it is concerned with power and authority. Local institutions of villages, towns, districts, provinces, counties, etc. are the sole foundations which can protect and promote the interest of a locality" (Thapa, 1998: 2). The distinctive forms of local governance have evolved due to the practical contextual differences and practices as follows (Quoted in Khanal, 2006: 1012). Based on various definitions and descriptions by international scholars and authorities, the local government and/or local governance may be divided into following different types.

\section{- Deconcentration}

Deconcentration can be defined as the transfer of power and function from the central level government organizations to their respective field level agencies enabling the latter to carry out their tasks efficiently and effectively. Kirsten (1993) says that deconcentration is the process of redistribution of administrative responsibilities within the central government, which might be used to consolidate the central government's power through field offices. For Maddick (1963), deconcentration is 'the delegation of authority adequate for the discharge of specified function to staff of a central department, who are situated outside the headquarters.' Rondinelli (1989) holds a similar view and states it 'merely involves the shifting of workload from central government ministry headquarters to the staff located in the offices outside of the national capital?' 
Deconcentration, however, does not allow the local units the freedom of decision making. The deconcentrated agencies need to get the consent of the central authority in making all kinds of decisions, but make it easier for the local people because they do not have to go to center for everything. In fact, the deconcentrated agencies are only the bureaucratic arms of the central government and do not actually help in strengthening local governance.

- Delegation

Delegation implies transfer or creation of broad authority to plan and implement decisions concerning specific matters - a variety of activities within specific spatial boundaries transferred to an organization that is technically and administratively capable of carrying them out. Some authorities and decision making power are delegated to local officials but the ultimate power remains with the central government and the delegated powers can be taken back by the center when it feels necessary.

\section{- Devolution}

Devolution is the process of transferring power from the central government to a lower level. It increases the efficiency of the government in meeting the demands from special sections of a community which may also enjoy some degree of control over its interests. It highlights "the legal conferring of powers to discharge specified or residual functions upon formally constituted local authority." Devolution is generally understood as the most extensive form of decentralization involving creating or strengthening independent levels and units of governments through direct assignment of decision-making responsibility.

\section{- Privatization}

Privatization is another form of decentralization. It is the act of reducing the role of government, or increasing the role of private sector, in an activity or in the ownership of assets. Privatization also encourages the involvement of private sector in state ownership and brings about efficiency and effectiveness in the management of national economy. It gives incentive to popular participation and contributes to enhancing the overall development process.

Like the types of decentralization, the objectives of decentralization, too, are different. The key purposes of decentralization can be summarized as follows (Lama, S. 2009: 29-30).

\section{- Political Decentralization}

It is the most important purpose of decentralization. It involves the process of taking the 
government and development closer to the people. It aims at transferring political power and authorities to the local level so that the elected representatives of the people are in the decision making positions. Decentralization can be ensured through legal and constitutional measures.

\section{- Fiscal Decentralization}

The purpose of this decentralization is the handover of the financial authority and resources to the local level. Without resources no authority or power can be effectively carried out or it may be argued decentralization without financial decentralization is no decentralization. Therefore, fiscal decentralization is crucial for the success of any kind of decentralization. Financial resources should be available to the local authorities in a manner that is sufficient and reliable to undertake the tasks devolved or functions they are supposed to carry out and services they are to deliver.

- Administrative Decentralization

As indicated by the name itself, the purpose is limited to administrative operation. It is a mere transfer of roles and responsibilities of planning, management and resource generation of the central authority to its selected field level units of governments, semi-autonomous public authorities and regional or functional authorities outside the regular bureaucratic structure for the delivery of services from the central government.

\section{- Market Decentralization}

The purpose of this decentralization is to usher in the involvement of private sector in government services and operation. It facilitates the involvement of private sector through market competition and gradually replaces the government from specific areas.

\section{Local Governance in Nepal}

Nepal is a diverse country in terms of geography, and ethnicity. It is situated in Latitude - $26^{\circ} 22^{\prime}$ $\mathrm{N}$ to $30^{\circ} 27^{\prime} \mathrm{N}$ - Longitude $80^{\circ} 4^{\prime} \mathrm{E}$ to $88^{\circ} 12^{\prime} \mathrm{E}$. Nepal is a land locked Country, China in the North, India in the South, East and West. It has an area of 147,181 Sq. Km. Nepal is inhabited by nearly 30 million people having density of 157 people per sq. $\mathrm{km}$ and with population growth rate of 1.35 percent. Average life expectancy of Nepali is around 71 years and literacy rate is 66 percent (Male 65\% and female 42.5\%). Nepal is characterized by diverse geographical regions including the high Himalayan mountains, trans-Himalayan region, the central highlands (hills) and the southern Terai. Over $85 \%$ of the people live in the rural areas. Nepal is a multiethnic, multi-lingual and multi-cultural country. There are approximately 23 Dalits (socially 
disadvantaged community or untouchable) castes and 59 Janajatis (indigenous nationalities) (CBS, 2019).

Nepal has a three-tier governance structure (One Federal Government, 7 Provincial governments, 753 Local governments and 77 districts). The third tier is the local government also known as local level. At the federal level, there is a bicameral parliament - the House of Representatives (HoR) and the National Assembly (NA). The HoR has 275 members including 165 elected through First Past the Post (FPTP) and 110 elected through Proportional Representation (PR) system (The Constitution of Nepal, 2015: 41). The National Assembly has 59 members (The Constitution of Nepal, 2015: 42). At the provincial level, there are unicameral assemblies in each of the seven provinces. Altogether there are 550 members in the provincial assemblies 330 members elected through FPTP and 220 elected through PR system (Election Commission of Nepal, 2018: 59-124).

There are local legislatures in each of 753 local level units. There are Village Assemblies in the Rural Municipalities and Municipal Assemblies in the Municipalities. The Constitution has provided law making authority to all three levels of legislatures. The Constitution provides for the formation of the structure of Village Executive including the election of chairperson, vice chairperson, ward chairperson and members. It also provides for the inclusion of four women members, and two members from Dalit or minority community. (The Constitution of Nepal, 2015: 98).

\section{Past Legal mechanisms of Nepalese Local Governance}

Local governments have been practiced in different forms since hundreds of years. During ancient Kirat/Malla period, they were utilized strictly for administrative and judicial purpose. The actual concept of local development through local governments started only after 1990 when democracy was restored in Nepal. Almost all of those practices were based on decisions of the central authority. It is after 1990 that one can find legal instruments specifically formulated to institutionalize sustainable elected local governance. The first major legal instrument on local government in Nepal is the Local Self Governance Act (LSGA) of 1999. It elaborated the formation, jurisdiction and procedures of the local units such as Village Development Committees (VDCs), Municipalities and District Development Committees (DDCs) (Local Self- Governance Act, 1999: 11)

The chiefs and members of VDCs and municipalities were elected on FPTP basis. The VDCs included one chairperson, one vice chairperson, 9 ward chairperson and 4 members from each 
ward. The municipalities included one mayor, one deputy mayor, and different numbers of ward chairperson based on its size and 4 members from each ward. The DDC included chairperson, deputy chairperson and members who were chosen by the VDCs and municipalities concerned. (Local Self- Governance Act and Regulation, 1999: 64). During the period when LSGA was active, there were 75 districts, 58 municipalities, 3913 VDCs, 36,041 wards of municipalities and VDCs, as well as 927 Ilakas of DDCs. Districts were considered as focal points, which were expected to work according to the concept of local development planning, implementing and monitoring to the availability of local resources as per the aspirations of the local people (Lama, 2009: 28).

Between 1999 and 2017, the local governments were run by un-elected bureaucrats or political bodies. Due to political and security situation, local elections could not be held in this period. "In the absence of elected people's representatives, the voices of people could not be heard. It is not possible for bureaucrats to understand the needs of the people. Since the established mechanism envisaged by Local Self Governance Act for the planning formulation, implementation and monitoring was absent, the Act could not be enforced as per its spirit. Bureaucrats had no pressure about planning. When plans were formulating that did not address people's needs, it was natural to see its impact on immediate implementation" (Adhikari, 2004).

In 2007, an Interim Constitution was promulgated in order to address the changed political context. For the first time, the interim constitution talked about restructuring of the state and federalism.

The first and fifth amendment of the Interim Constitution made drastic changes in the provisions related to state structure and local self-governance. Part 17 of the Interim Constitution (Article 138140) is dedicated to the local self-governance. The Article 138 titled Progressive Restructuring of the State stated that the centralized and unitary nature of the state shall be restructured into democratic federal system of governance to end the class-based, ethnic, lingual, gender, cultural, religious and regional discriminations. The Article 139 titled Provision for Local Self Government stated that local level elections shall be held on the basis of decentralization and devolution in order to institutional democracy from the grassroots and to provide service to the people from the local level itself (The Interim Constitution, 2007: 67-68). The Interim Constitution was later replaced by the new constitution promulgated by the elected Constituent Assembly.

For the first time in the history of Nepal, people elected constituent assemblies (CA) to write their constitution. Two CAs were elected in 2008 and 2013. The first CA could not deliver constitution due to deep political differences on matters such as federalism and state restructuring. 
The second CA delivered the constitution in 2015. Both the CAs held extensive debates regarding the form and nature of local governments. There were 11 thematic committees in first CA and only 5 in second CA. The first CA had one Committee on State Restructuring and Division of State Power. This committee had widely discussed the issue of local governments. It laid down two major bases of local government-Identity and Capacity. Under the Identity, it divided the base into five sub-bases - ethnic/community, lingual, cultural, territorial/regional continuity, and historic continuity. Likewise, under the Capacity, it divided the base into four sub-bases Economic Inter-relation and Capacity, State of Infrastructure and Potential, Natural Resources and Availability, and Administrative Ease. The second CA largely owned the documents and agreements reached by the first CA (CA Committee of State Restructuring and Division of State Power, 2010: 20-21).

In fact, the objective of the democracy is to transform the traditional character of the state into transparent political system and to responsibly and cooperatively manage the conflicting interests through open dialogue. To maintain relative peace and order in the country and society, and to stem the spread of violence and armed conflict, a lot depends on the characteristics of the state operation system. The countries that have democratic, representative and participatory system of governance can achieve relative peace. Causes and grounds for violence and armed conflict are largely reduced in such countries and societies (Khanal, Pradhan, Acharya, Thapa, Rijal, Giri, 2007).

The Constitution of Nepal 2015 promulgated by the elected constituent assembly established local level as full-functional local government units. Article 56 of the Constitution states about the structure of the state and designates three tiers of governance - federal, provincial and local level. Article 56 (2) states, "The state power of Nepal shall be exercised by the federal, province and local level as per this constitution and laws." According to the Constitution there has been mentioned in Part 17 provisions about Local Executive; Part 18 of the Constitution provides for Local Legislative; Part 19 of the Constitution provides for Local Financial Management; and Part 20 provides for inter-relations among federal, province and local level. The local level currently has Rural Municipal and Municipal Executive, that function as executive branch; Rural Municipal and Municipal Assembly that function as legislative branch; and Rural Municipal and Municipal Judicial Committees that function as judicial branch.

Likewise, the Constitution provides for the formation of the structure of Municipal Executive including the election of chairperson, vice chairperson, ward chairperson and members. It also provides for the inclusion of five women members, and three members from Dalit or minority 
community (The Constitution of Nepal, 2015: 99). They are expected to make laws on specified areas. Schedule 5 of the Constitution has provided a list of 35 areas in which the federal legislature has exclusive right for law making (The Constitution of Nepal, 2015: 173). Likewise, Schedule 6 has provided a list of 11 areas in which the provincial assemblies have exclusive right for law making (The Constitution of Nepal 2015: 175). Schedule 7 has provided a list of 21 areas in which the federal and provincial legislatures have concurrent rights for law making (The Constitution of Nepal 2015: 176). Schedule 8 has provided list of 22 areas in which the local legislatures have exclusive rights for law making (The Constitution of Nepal, 2015: 179). Schedule 9 has provided a list of 15 areas in which the federal, provincial and local level legislatures have concurrent rights for law making (The Constitution of Nepal, 2015: 181).

The Schedule 8 of the Constitution defines the exclusive rights of the local level. It states that there will be 22 areas under such local level jurisdiction. They include city police, co-operative, local taxes, management of local service, basic and secondary education, local level development projects, basic health and sanitation, local road, distribution of land/house ownership certificate, agriculture and livestock management, disaster management and so on.

\section{Restructuring of Local Government and Operation Act}

After the promulgation of the Constitution in 2015, the government formed a Local Level Restructuring Recommendation Commission (LLRC) headed by Balananda Poudyal. The Commission recommended the formation of 753 local government units including 6 Metropolitan Cities, 11 Sub metropolitan Cities, 276 Municipalities, 460 Rural Municipalities and 6,473 wards of local government. The Commission identified seven major bases for the restructuring and delimitation of the local government units. The bases included minimum ceiling of population; geography and area; ethnic/lingual/cultural density; bases of geographic accessibility; natural resources; institutional infrastructure; and potential of income/expenditure based on fiscal year 2015/16. The Commission mobilized its district committees in 77 districts. The Local Development Officer headed the committees called technical cooperation committees. Their reports were reviewed and the Commission came up with final division based on them (LLRC Report, 2017).

The elections for these local levels were held in 2017 electing around 37,000 representatives. Out of the total, 15,000 were women and from Dalit community. In order to ensure inclusion, the laws made it mandatory that chairperson/mayor and vice chairperson/deputy mayor of Rural Municipality/ Municipality must represent different gender. It indicates the size and the 
overwhelming pressure that if property designed and implemented, could have significant impact not only in strengthening democracy but also in delivering services to the people.

In 2017, Nepal completed all three sets of elections that were necessary to institutionalize the three tiers of governance adopted by the Constitution of Nepal. The elections led to the formation of governments and legislatures at the federal, provincial and local level. In particular, the seven provincial governments and provincial assemblies were formed - as totally new structures in the history of Nepal. In the first set of federal, provincial and local level elections, the unified force of communist party gained big majority. In federal parliament, the Nepal Communist Party formed a government with two-third majority support. In 6 out of 7 provinces, the same party formed government with either two-third or comfortable majority. Nepali Congress became the main opposition party. Some Terai-based parties were the third force. Similarly, the NCP, NC and Terai-based parties won most of the seats in the local government election (Election Commission of Nepal, 2019).

A separate Local Government Operation Act, 2018 (LGOA) was formulated in 2018 after the elections. It laid down clear provisions on formation process of Rural Municipality and Municipality; their functions, roles and responsibilities; their rule of procedure, planning, implementation and coordination; and the formation and rights of the judicial committees. These provisions have established legislative, executive and judicial functions of the local level. The LGOA has 121 Clauses that range from number and delimitation of rural municipalities and municipalities to their formation, nature and functions (Ministry of law, Justice and Parliamentary Affairs, 2016). The LGOA states that the local level shall work in the spirit of cooperation, coexistence and coordination to promote people's participation, accountability and transparency in the delivery of quality service. It aims to ensure the proportional, inclusive and judicious distribution of democratic dividend to consolidate socialism-oriented federal democratic republican system from the local level. The main focus of the LGOA is on the development of local leadership to strengthen local governance system through the exercise of local level executive, legislative as well as judicial powers.

\section{Service Delivery of Local Governance}

The major function of local governments is delivering various services to the people. In the current form, there are two important units of the local government, namely; Rural Municipalities and Municipalities. Interestingly, in the previous system, districts were the central units for local governance. However, they have now been replaced by the Rural Municipalities or 
Municipalities. The Rural Municipalities and Municipalities are the primary policy making body of the local governments whereas the primary implementing units are the Wards. The current Rural Municipalities or Municipalities have been formed by merging 4-6 VDCs or municipalities. Their size and population are bigger. In fact, the current Wards are as much bigger or slightly smaller than previous VDCs.

Previously, there used to be a single VDC secretary designated by the central government to help the administration. But now each Rural Municipality or Municipality has joint or undersecretary level official as administrative chief. They also have 50-70 staffs dispatched by the central government. Each Rural Municipality/Municipality has formed half a dozen committees to implement different activities. The LGOA has clearly stipulated the functions, duties and rights of the local governments. It has provided executive, legislative as well as judicial functions and rights. The Rural Municipal Executive and Municipal Executive work as local executive bodies. The Rural Municipal Assembly and Municipal Assembly work as local legislatures. The Judicial Committees work as local judiciary.

On the executive front, the local governments have started spending resources on service delivery as well as local development. Each Rural Municipality has a total budget between Rs 400 million to Rs 1 billion. Likewise, each Municipality has total budget between Rs 1 billion to Rs 15 billion. But the huge portion of this budget is provided as grants by the federal and provincial governments. Most of these local governments are using maximum resources - apart from incurring regular expenditures like salary - on building roads without proper planning. In terms of service delivery, the current local governments have improved the quality and access compared to previous system. However, the fees imposed on service recipients have increased dramatically.

Chairperson, National Rural Municipality Association of Nepal, Hom Narayan Shrestha says most of the federal budgets that are transferred to the local government are conditional grants. This limits the rights of the local government in spending resources in the areas they see fit. General Secretary, National Rural Municipality Association of Nepal, Bansalal Tamang says there is confusion in the spending of resources. Federal, province as well as local governments are found spending money on similar kind of projects. There is no uniformity and lot of duplications. General Secretary, Municipal Association of Nepal Bhim Dhungana says the idea of providing separate fund to the MPs in federal and province parliament is inconsistent with the concept of local governance. There are elected local governments that can better use such resources. The responses of these local leaders reveal that both in roles as well as resources there is a huge paucity meaning that the local governments have not been able to deliver services as enshrined in 
the constitution or as expected by the people.

On the law making front, even though they are allowed to formulate laws on 22 areas as listed in Schedule 8 of the constitution, very few local governments have taken the initiative on law making. Even among the local governments that have started initiative on law making, most have relied on the model laws dispatched by the federal government. Most local governments appear confused about their rights on exclusive list and concurrent list.

Chairperson, National Assembly Ganesh Prasad Timilsina says the federal parliament is currently formulating a law on coordination among federal, province and local level. Only after it is formulated can the provinces and the local level become clear about their responsibilities in law making. Speaker of the Province Assembly of Karnali Province Raj Bahadur Shahi says provinces and local level should be allowed to formulate laws on their appropriate time. Otherwise, it will hinder their service delivery and development. In any case, laws that are inconsistent with the federal or province laws can be annulled to the extent they are inconsistent. Chairperson, Constituent Assembly Subas Nemwang says local governments can frame laws immediately on 22 areas in Exclusive List and 15 areas in Concurrent List. But as the constitution says, such laws have to be annulled if they are inconsistent with the province or federal laws - to the extent they are inconsistent. Therefore, it will be appropriate for the local governments to appoint legal officers so that they can avoid such inconsistencies. Chairperson, Singta Rural Municipality of Surkhet, Kabindra Kumar KC says the Rural Municipalities have been working as per the LGOA. But at most points we need laws and policies. Therefore, the primary concern should be on law making, without which we cannot move forward.

They further argue the inadequacy of proper laws mandates and guidelines to leisure smooth functioning. On the judicial front, the judiciary committees of the local governments are functional and are delivering judicial service to the local people. By providing justice through short due process at the doorsteps, these committees have given a huge relief to thousands of people. There is a growing trend of people approaching the committees seeking justice. Particularly, people from poor community, women and Dalits have benefitted from the new dispensation.

However, out of 753 local governments, dozens of them have not formed judiciary committee yet because of political reasons. Even in local governments that have formed the committee, they lack budget, infrastructure, human resource as well as conceptual clarity.

The Clause 47 (1) and (2) of the LGOA provide judicial functions and rights to the judiciary committees of the local governments. Clause 47 (1) has 13 areas and 47 (2) have 11 areas. 
Under the first clause, the local governments can adjudicate whereas under the second clause they can only hold mediation. According to a study by Nepal Law Society, most of the people approach the judiciary committee only to settle cases under Clause 47 (2).

Former Chief Justice Kalyan Shrestha says the judiciary committees of the local government have to deliver judicial functions, which require application of judicial mind and adoption of due process. If they do not follow these norms, their decisions can be overturned by the district courts. Therefore, it is necessary to develop judicial capacity among the members of the judicial committee. An official training manual should be developed and based on the manual all of the committee members should be trained. Chief Judge of High Court Til Prasad Shrestha says Judicial committees have failed to follow due process because of which many of their decisions have been overturned by district courts. Delivering justice is not enough. It has to be delivered through due process. Deputy Mayor, Mithila Municipality of Dhanusha, Tara Lama Basnet says the Mayors control everything while the Deputy Mayors have no power or control. There is a lack of resources to administer the judicial committee. There is no meeting place or even legal support available. There is political interference in every sphere of our work. The district court only engages with the mayors while deputy mayors should be equally engaged due to their judicial role. Women deputy mayors need regular trainings, preferably once every three months, for their capacity enhancement. Such trainings should also include the mayors so that they understand the work of judicial committees and their importance. Deputy Mayor, Hansapur Municipality of Dhanusha, Renu Devi Jha says in the absence of resources, it has become extremely difficult to work and deliver services. The deputy mayors have multiple responsibilities; from judicial committees to budget, to planning as well as monitoring. However, the deputy mayors have not been able to do justice to their role. The mayors have all the facilities as well as support to run their office, but the deputy mayors have no personal assistance or any other support. Although the right to head the judicial committee is given to vice chairperson or deputy mayor, they face challenge from chairperson or mayor because most of the deputies are women. Women face cultural problem due to male domination. The evidence further enforce wellnesses in delivering services in the judicial front too.

\section{Practical Challenges Faced by Local Governments}

Through the elections in 2017, most of the positions of vice chairperson of Rural Municipality and deputy mayor of Municipality are occupied by women. The LGOA gives huge responsibilities to vice chairperson of Rural Municipality and deputy mayor of Municipality. 
The Clause 16 (4) (b) of the LGOA lists responsibilities of the vice chairperson of Rural Municipality and deputy mayor of Municipality. They are given important responsibility such as working in the capacity of coordinator of the judicial committee; and duty of monitoring and supervision of planning and implementation. The Clause 65 states that they work as coordinator of Local Revenue Advisory Board. The Clause 67 states that they work as coordinator of Budget and Program Drafting Committee. These clauses show that most important responsibilities are given to vice chairperson of Rural Municipality and deputy mayor of Municipality. But given the cultural dominance by men who are in the position of chairperson or mayor, they face lots of challenges in asserting their rights.

\section{Conclusion}

Nepal, despite transforming to a federal republic with three tiers according importance to local levels as is enshrined in the constitution and the laws, is finding it difficult to empower local level making them fully functional due to paucity of resources, conflict in resource distribution and empowering notwithstanding the elections and the designing of the Acts. In the execution of previous laws like LSGA 1999, it encountered numerous impediments proving real decentralization to be a tough task in view of not only socio-cultural and resource context of the country but aided by reluctant bureaucracy and the power centers not willing to shed power where it is needed. Even during the federalization process, these barriers have strongly emerged. However, democracy, if it is to mean meaningful empowering of people, has to empower bodies working nearest to the people, the local levels, and only this will lead to realization of the goals envisioned in the constitution.

Presently, there have been a lot of positive developments and steps taken towards the right direction. The local governments have been elected and they have gradually started working in law making, service delivery as well as development. However, in each of these fields, they have faced challenges relating to capacity, knowledge and resources planning that they have not delivered services as is expected.

\section{Recommendations}

Given the afore-mentioned gap in the constitutional provisions and the actual practice in local governance, there are some clear recommendations that can help in addressing them. These recommendations are presented below under specific categories

\section{- Policy}


There is a need to have a five-year policy to implement local governance based on the Constitution, and Directive Principles of the State. Based on this long term policy, annual policy and laws should be formulated. The Local Level Assembly should pass the policy in coordination among federal, province and local level. Draft a policy to embrace the rights enshrined in the Schedules of the Constitution ( $8 \& 9$ ).

\section{- Legal}

Laws to operationalize the 22 rights enshrined under exclusive list in Schedule 8 of the constitution should be formulated soon. Likewise, laws to operationalize the 15 rights enshrined under concurrent list in Schedule 9 of the constitution should also be formulated quickly. To make this process clearer, the federal level should first make the law on coordination ready. The federal and province should coordinate and consult with the local level when they formulate their laws that are relevant to local level.

\section{- Capacity Development}

There is a need to provide adequate human resources in coordination with the federal and province governments. Hold training for the elected representatives of local level to understand and implement the Local Governance Operation Act. The staffs of the local level should also be trained on law making, service delivery, economic policy, planning and judicial functions. The staffs of local level should be made accountable to the local level. The officials of Judicial Committees should be trained and provided with Guidelines on Judicial Service Delivery.

\section{- Institution Building}

There is a need to develop physical infrastructures for local level with long term vision in mind. Focus should be on building institutions of wards as centers for service delivery along with basic facilities to local level offices.

\section{- Human and Financial Resources}

There is a need to prepare properly Organization strengthen at of Local Level, identify the necessary positions and fill them accordingly. Human resources should be made accountable to local level governments. The National Natural Resource and Fiscal Commission should be effective and should ensure sustainable financial resources for the local level. Volumes of conditional and non-conditional grants for local level should be specified. Areas of local resources and their management should be identified. 
- Development/Service Delivery

There is a need to prepare 5-year development strategy plan, and guideline for service delivery mechanisms. It should be ensured that the citizens receive services at their doorsteps.

\section{Reference}

Adhikari, Yagya Prasad (2004). Local Governments Without Elected Representatives - A Study, Kathmandu: DASU/DANIDA.

Badal, Bharat, Prasad (2019). Roles of Rahul Sankrityayan in Nepalese Cultural Tourism, Research Nepal Journal of Development Studies, Volume 2 Issue 1 Pages 13-2: Kathmandu

Bhattarai, Ghanashyam (2008). History of Local Administration of Nepal, New Delhi: Adroit Publication.

Byrne, Tony (1981). Local Government in Britain, Britain: Penguin Books.

Constituent Assembly (2010). Report on Concept Paper and Preliminary Draft, Committee of State Restructuring and Division of State Power, Kathmandu: Constituent Assembly, GoN.

Daily Express News (2 August 2013). "All-party meet vows to uphold Parliament supremacy". The New Indian Express. Express Publications (Madurai) Limited: Retrieved 18 August 2013.

Diamond, L. (2004). Lecture at Hilla University for Humanistic Studies 21 January: "What is Democracy"; Diamond, L. and Morlino, L., The quality of democracy (2016). In Diamond, L., In Search of Democracy. London: Routledge.

Election Commission of Nepal (2018). Election Result Book, Members of House of Representatives, 2018, Kathmandu: Election Commission.

Election Commission of Nepal (2018). Election Result Book, Members of Provincial Assemblies, 2018, Kathmandu: Election Commission. 
Government of Nepal (2007). The Interim Constitution of Nepal, Nepal Government, Ministry of law, Justice and Parliamentary Affairs of Government of Nepal, Kathmandu: Law Book Management Board.

(2015). The Constitution of Nepal, Government of Nepal, Ministry of law, Justice and Parliamentary Affairs of Government of Nepal, Kathmandu: Law Book Management Board.

..(2016). Identification and Prioritization of Laws Necessary for the Implementation of the Constitution and the Current State of Law Making, Kathmandu: Government of Nepal, Ministry of Law, Justice and Parliamentary Affairs)

(2019). National Planning Commission, Kathmandu: Central Bureau of Statistics.

(2018). Local Government Operation Act, Kathmandu: Ministry of Law, Justice and Parliamentary Affairs of Government of Nepal, Law Book Management Board.

Haney, J. (1944). Of the People, by the People, for the People. Proceedings of the American Philosophical Society.

His Majesty's Government of Nepal (1999). Local Self Governance Act, Kathmandu: Ministry of Law, Justice and Parliamentary Affairs of His Majesty's Government of Nepal, Law Book Management Board.

(1999): Local Self Governance Regulation, Kathmandu: Ministry of Law, Justice and Parliamentary Affairs of His Majesty's Government of Nepal, Law Book Management Board.

Khanal, Pradhan, Acharya, Thapa, Rijal, Giri (2007). Restructuring of the State and Transformation, Kathmandu: National Peace Campaign.

Khanal, Rabindra (2006). Local Governance in Nepal Democracy at Grassroot, Kathmandu: Smriti Books.

Lama, Sangram Singh (2009). Decentralized Local Governance: Rhetoric and Practice in Nepal Since 1950s, Kathmandu: A Dissertation of Doctor of Philosophy (Phd) in Sociology.

Local Level Restructuring Commission (2018). Report of Local Level Restructuring Commission, 
Government of Nepal, Kathmandu: LLRC Commission.

Locke, John (2009). Two Treatises on Government: a Translation into Modern English: Google Books.

Ministry of Housing, Communities \& Local Government Government UK (2016). Local Government Structure and Elections, Published 11 January. England: UK Government.

Przeworski, Adam (1991). Democracy and the Market, Cambridge University Press: 10-14.

Shrestha, Tulsi Narayan (1996): The Concept of Local Government and Decentralization, Kathmandu: Ratna Pustak Bhandar.

Sisk, Timothy D. (2001). Democracy at the Local Level, Sweden: International Institute for Democracy and Electoral Assistance (International IDEA).

Suhrke, Astri (2016). Conflict, Security \& Development Volume 16, 2016 - Issue 6: Elections and the state: critical perspectives on democracy promotion in Afghanistan.

Thapa, Ganga Bahadur (1998). Local Self- Government in Nepal, Kathmandu: Political Science Association of Nepal (POLSAN).

UK Parliament (2014)."Parliamentary sovereignty". Retrieved 18 August 2014; "Independence". Courts and Tribunals Judiciary. Retrieved 9 November 2014

Watkins, Frederick (1970). "Democracy" Encyclopedia Britannica. 7 (Expo '70 hardcover ed.) London: William Benton: 215-23. 